\title{
PENGARUH RETURN ON ASSETS (ROA), RETURN ON EQUITY (ROE) DAN PRICE EARNING RATIO (PER) TERHADAP HARGA SAHAM PERUSAHAAN PERBANKAN YANG TERDAFTAR DI BURSA EFEK INDONESIA
}

\author{
Hasniawati \\ Sekolah Tinggi Ilmu Pancasetia Banjarmasin \\ Jl. A. Yani Km. 5.5 Banjarmasin \\ e-mail:nhiakhunnie@gmail.com
}

\begin{abstract}
The purpose of this study is to determine the Return On Assets (ROA), Return On Equity (ROE), and Price Earning Ratio (PER) simultaneously and partially influence the stock prices of banking companies listed on the Indonesia Stock Exchange. The data used in this study is secondary data from the Indonesia Stock Exchange through its official website www.idx.co.id. The data collected are closing price data, Return On Assets (ROA) data, Return On Equity (ROE) data and Price Earning Ratio (PER) data from banking companies in 2018. Data processing is performed using a multiple linear regression statistical test with SPSS version 20. The results of this test prove that the independent variables consisting of ROA, ROE, and PER simultaneously have a significant effect on the stock prices of banking companies that go public in Indonesian Stock Exchange. The results of this test also prove that ROA, ROE, and PER partially have a significant effect on the stock prices of banking companies that go public in Indonesia Stock Exchange.
\end{abstract}

Keywords: ROA, ROE, PER, and Share Prices.

Abstrak. Tujuan Penelitian ini adalah Untuk mengetahui Return On Assets (ROA), Return On Equity (ROE), dan Price Earning Ratio (PER) bepengaruh secara simultan dan parsial terhadap harga saham pada perusahaan perbankan yang terdaftar di Bursa Efek Indonesia. Data yang digunakan dalam penelitian ini adalah data sekunder data dari Bursa Efek Indonesia melalui situs resminya www.idx.co.id. Data yang dikumpulkan adalah data harga saham (closing price), data Return On Assets (ROA), data Return On Equity (ROE) dan data Price Earning Ratio (PER) dari perusahaan perbankan tahun 2018. Pengolahan data dilakukan dengan menggunakan uji statistik regresi linear berganda dengan alat SPSS versi 20. Hasil pengujian ini membuktikan bahwa variable independen yang terdiri dari ROA, ROE, dan PER secara simultan berpengaruh signifikan terhadap harga saham perusahaan perbankan yang go public di bursa efek indonesia. Hasil pengujian ini membuktikan juga ROA, ROE, dan PER secara parsial berpengaruh signifikan terhadap harga saham perusahaan perbankan yang go public di bursa efek indonesia.

Kata kunci: ROA, ROE, PER, dan Harga Saham. 


\section{Latar Belakang}

Pasar modal merupakan salah satu alternatif yang dapat dimanfaatkan perusahaan untuk memenuhi kebutuhan dananya. Peranan pasar modal di suatu negara sangatlah besar karena dinamisnya aktivitas pasar modal di suatu negara menggambarkan begitu baiknya kondisi iklim bisnis di negara yang bersangkutan. Pasar modal salah satu alternatif investasi bagi masyarakat. Melalui pasar modal, investor dapat melakukan investasi di beberapa perusahaan melalui pembelian surat-surat berharga yang ditawarkan di pasar modal (Sri Hermuningsih 2012 : 2).

Keberadaan pasar modal di suatu negara dapat menjadi acuan untuk melihat bagaimana kegaurahan atau dinamisnya bisnis di sebuah negara menggerakkan kebijakan ekonominya seperti kebijakan fiskal dan moneter. Dari kebijakan yang diterapkan tersebut kondisi stimulus dan bahkan ketahahan bisa diperoleh dengan efek lebih jauh mampu memberikan kontribusi positif pada pendapatan negara terutama dari segi pendapatan pajak (Irham, 2013:54).

Saham perbankan merupakan saham yang paling diminati karena sektor perbankan merupakan salah satu sektor yang sangat penting bagi suatu negara. Keberadaan perbankan akan berlangsung lama dan akan terus berkembang dari waktu ke waktu. Sektor perbankan membuktikan eksistensinya dalam kinerja dan pencapaian hasil yang cukup baik dengan memiliki kapitalisasi pasar dan likuiditas yang tinggi. Bahkan beberapa saham perbankan yang go public yang tercatat di BEI memiliki kenaikan harga yang pesat dan termasuk dalam kategori saham yang paling aktif.

Investor perlu memiliki sejumlah informasi yang berkaitan dengan dinamika harga saham agar dapat mengambil keputusan tentang saham perusahaan yang layak untuk dipilih. Salah satu faktor yang mendukung kepercayaan pemodal adalah persepsi mereka akan kewajaran harga saham. Pasar modal dikatakan efisiensi apabila harga sekuritas-sekuritasnya mencerminkan semua informasi yang relevan. Informasi yang tepat akan kewajaran harga saham dapat membuat para investor terhindar dari kerugian membuat keputusan dalam melakukan investasi saham.

Seorang investor yang akan menginvestasikan dananya pada suatu perusahaan tertentu, hendaknya melakukan analisis kinerja dari perusahaan yang bersangkutan. Kinerja keuangan perusahaan perlu untuk dianalisis terlebih dahulu agar investor tidak salah dalam memilih saham dan terjebak dengan saham dengan kondisi keuangannya yang buruk. Semakin baik kinerja suatu perusahaan maka semakin besar pengaruhnya terhadap kenaikan harga saham. Begitu juga sebaliknya, semakin menurun kinerja suatu perusahaan maka kemungkinan besar merosotnya haga saham yang diterbitkan dan diperdagangkan. Keadaan perusahaan akan menjadi tolak ukur seberapa besar risiko yang akan ditanggung oleh investor.

Untuk memastikan apakah kondisi perusahaan dalam posisi yang baik atau buruk dengan menggunakan analisis fundamental melalui analisis rasio salah satunya Return On Assets (ROA), Return On Equity (ROE) dan Price Earning Ratio (PER).

Return On Assets (ROA) digunakan untuk mengukur keuntungan bersih yang diperoleh dari penggunaan aktiva. Semakin besar ROA maka semakin baik karena tingkat keuntungan yang dihasilkan perusahaan dari pengelolaan asetnya semakin besar. Jika pengelolaan asset yang semakin efisien maka tingkat kepercayaan investor terhadap perusahaan akan meningkat yang nantinya akan meningkatkan harga saham (Abigael dan Ika, 2008 : 78).

Return On Equity (ROE) digunakan untuk mengukur besarnya pengembalian terhadap investasi para pemegang saham. Rasio ini tersebut menunjukkan seberapa baik manajemen memanfaatkan investasi para pemegang saham. ROE merupakan perbandingan antara pendapatan setelah pajak dengan modal sendiri. Kenaikan 
ROE biasanya diikuti oleh kenaikan harga saham sebuah perusahaan. Semakin besar ROE semakin besar pula harga saham karena besarnya ROE memberikan indikasi bahwa pengembalian yang akan diterima investor akan tinggi sehingga investor akan tertarik untuk membeli saham tersebut dan hal itu menyebabkan harga pasar saham cenderung naik (Harahap, 2007 : 156).

Price Earning Ratio (PER) untuk mengukur kemamupan perusahaan dalam menciptakan laba yang tersedia bagi pemegang saham. Semakin rendah hasil PER sebuah saham maka semakin baik atau murah harganya diinvestasikan. Dalam menghitung berapa kali nilai pendapatan yang tercermin dalam harga suatu saham. Rasio ini mengindikasikan derajat kepercayaan investor pada kinerja masa depan perusahaan. Semakin tinggi PER, investor semakin percaya pada perusahaan sehingga harga saham semakin mahal (Darmadji dan Fakhruddin, 2006 : 198).

Invenstor di pasar modal sangat memperhatikan kemampuan perusahaan untuk menghasilkan dan meningkatkan profit. Profitabilitas dapat diukur melalui Return On Asset (ROA), Return On Equity (ROE), dan Earning Per Share (EPS). Penilaian bahwa faktor profitabilitas sesuai dengan ketetapan Bank Indonesia pada Surat Edaran Bank Indonesia No. 13/24/DPNP menyatakan bahwa faktor profitabilitas diukur dengan rasio Return On Asset (ROA). Return On Asset (ROA) digunakan manajemen untuk mengukur keberhasilan dalam menghasilkan laba. Return On Asset (ROA) pengembalian atas aktiva merupakan suatu ukuran keseluruhan profitabilitas perusahaan, rasio ini membandingkan imbalan untuk pemegang saham dan kreditor dengan jumlah aset. Rasio ini digunakan mengukur kemampuan tingkat efektivitas penggunaan asset dalam menghasilkan laba bersih dalam suatu perusahaan.

Berdasarkan pada latar belakang yang telah diuraikan diatas, rumusan masalah penelitian ini sebagai berikut :
1. Apakah Return On Assets (ROA), Return On Equity (ROE), dan Price Earning Ratio (PER) berpengaruh secara simultan terhadap harga saham pada perusahaan perbankan yang terdaftar di Bursa Efek Indonesia?

2. Apakah Return On Assets (ROA), Return On Equity (ROE) dan Price Earning Ratio (PER) berpengaruh secara parsial terhadap harga saham perusahaan perbankan yang terdaftar di Bursa Efek Indonesia?

\section{Studi Literatur}

Keputusan investasi merupakan keputusan penggunaan dana yang dapat membuat pemilik dana menjadi kaya atau lebih makmur, keputusan penggunaan dana tersebut merupakan keputusan untuk memilih investasi perusahaan dalam melakukan kegiatan operasionalnya. Keputusan pendanaan atau keputusan pemenuhan kebutuhan dana merupakan keputusan untuk memilih jenis dana yang akan digunakan dalam kegiatan operasi perusahaan, keputusan pemenuhan kebutuhan dana tersebut dianggap benar, apabila dapat menurunkan biaya modal yang dipergunakan perusahaan. Keputusan kebijakan dividen merupakan keputusan untuk membagikan laba kepada pemegang saham atau pemilik perusahaan yang disebut dividen, atau menahan laba untuk keperluan diinvestasikan kembali dalam perusahaan. Kebijakan dividen ini dapat dikatakan tepat, apabila kebijakan tersebut dapat membuat pemilik modal, dalam hal ini pemilik perusahaan menjadi lebih makmur.

Dengan demikian dapat dikatakan, bahwa tujuan pengambilan keputusan keuangan adalah untuk dapat meningkatkan nilai perusahaan, yang berarti dapat meningkatkan kemakmuran pemilik perusahaan, dalam hal ini pemegang saham perusahaan yang bersangkutan, bagi perusahaan yang go public.

Manajemen keuangan merupakan suatu bidang pengetahuan yang cukup menyenangkan sekaligus menantang, 
karena mereka yang senang dalam bidang manajemen keuangan akan mendapatkan kesempatan yang lebih luas untuk memperoleh pekerjaan seperti corporate finance managers, perbankan, real estate, perusahaan asuransi bahkan sektor pemerintahan yang lain, sehingga karir akan berkembang (Musthafa:2013:1).

Pentingnya manajemen keuangan, seperti dikemukakan diatas, bahwa mempelajari Manajemen Keuangan (Financial Management) dapat menjelaskan tentang beberapa keputusan yang harus dilakukan yaitu keputusan investasi, keputusan pendanaan atau keputusan pemenuhan kebutuhan dana dan keputusan kebijakan dividen.

Dalam manajemen keuangan, apabila gagal dalam melakukaninvestasi, maka perusahaan tidak akan memperoleh keuntungan dari investasi tersebut, bahkan setiap tahun akan mengalami kerugian dari investasi tersebut. Begitu pula apa bila gagal dalam perdanaan atau dalam memperoleh dana, maka perusahaan akan selalu mengalami hambatan dalam melakukan kegiatan produksi, seperti mendapatkan bahan mentah atau bahan baku, sehingga produksi tidak bisa berjalan dengan lancar, begitu pula dengan pemasaran seperti melakukan promosidan kegiatan penjualan, sehingga pemasaran barang tidak bisa berjalan dengan baik, serta untuk membayar sumber daya manusia dalam melaksanakan kegiatan operasi perusahaan tidak dapat dilakukan dengan baik, karena dalam memperoleh dana harus dilakukan dengan tepat, agar kegiatan perusahaan dapat berjalan dengan lancar.

Hubungan ilmu ekonomi mikro,
yang mempelajari rumah $\begin{gathered}\text { tangga } \\ \text { perusahaan, sangat bermanfaat karena }\end{gathered}$
merupakan dasar bagi menajemen
pemasaran. Ilmu ekonomi mikro,
mempelajari ekonomi secara luas dan
bersifat global, seperti inflasi, kurs rupiah
terdapat mata uang asing, tingkat bunga
dan lain-lain, sangat bermanfaat dalam
mempelajari perilaku pasar secara makro.
Pengaruh besar lainnya terhadap kegiatan

perusahaan. Dari ilmu ekonomi makro adalah kebijakan fiskal dan moneter.

Dengan kemajuan dan perkembangannya ekonomi dan bisnis, maka manajemen pembelanjaan berubah nama menjadi manajemen keuangan. Manajeme keuangan kegiatannya lebih luas, yaitu manajer keuangan selain mencari dana, juga bagaimana menggunakan dana tersebut agar memperoleh keuntungan lebih besar (efisiensi).

Keuangan dianggap penting, karena perusahaan dalam operasionalnya memerlukan real assets atau aktiva yang nyata digunakan perusahaan yang semuanya harus dibayar, misalnya real assets yang berwujud seperti mesin, gedung pabrik, kantor, tanah, peralatan dan lain-lain. Sedangkan yang tidak berwujud seperti merk dagang, tenaga ahli dan lain-lain (Musthafa:2013:3).

1. ROA

ROA adalah rasio yang digunakan untuk mengukur keuntungan bersih yang diperoleh dari penggunaan aktiva. Dengan kata lain, semakin tinggi rasio ini maka semakin baik produktivitas asset dalam memperoleh keuntungan bersih (Lestari dan Sugiharto, 2007 : 196). Hal ini selanjutnya akan meningkatkan daya tarik perusahaan kepada investor. Peningkatan daya tarik perusahaan perusahaan menjadikan perusahaan tersebut makin diminati investor, karena tingkat pengembalian akan semakin besar. Hal ini juga akan berdampak bahwa harga saham dari perusahaan tersebut di Pasar Modal juga akan semakin meningkat sehingga ROA akan berpengaruh terhadap harga saham perusahaan.

ROA yang secara konsisten terus tinggi merupakan tanda manajemen yang efektif. ROA bisa diintrepretasikan sebagai hasil dari serangkaian kebijakan perusahaan (strategi) dan pengaruh dari faktorfaktor lingkungan (enviromental factors). Analisis difokuskan pada profitabilitas aset dan dengan demikian 
tidak memperhitungkan cara-cara untuk mendanai aset tersebut.

2. $\mathrm{ROE}$

Return on Equity (ROE) atau rasio hasil pengembalian total ekuitas, rasio ini mengukur kemampuan perusahaan menghasilkan keuntungan dari ekuitas/modal yang dimilikinya, dimana makin tinggi rasio ini maka makin baik (Salma Said, 2012 : 59). Angka ROE yang semakin tinggi memberikan indikasi bagi pemegang saham bahwa tingkat pengembalian investasi makin tinggi. Menurut Lestari dan Sugiharto (2007 : 196) dalam Rinati (2008 : 7) angka ROE dapat dikatakan baik apabila lebih besar dari $12 \%$.

3. PER

Dalam pendekatan PER, investor akan menghitung berapa kali (multiplier) nilai earning (pendapatan) yang tercermin dalam harga suatu saham. Pendekatan ini mmeberikan informasi berapa nilai rupiah harga yang harus dibayar investor untuk memperoleh setiap Rp 1 pendapatan perusahaan. PER juga merupakan ukuran harga relatif dari sebuah saham perusahaan.

4. Saham

Saham adalah kertas yang tercantum dengan jelas nilai nominal, nama perusahaan, dan diikuti dengan hak dan kewajiban yang telah dijelaskan kepada setiap pemegangnya, menurut Fahmi (2012:81). Saham merupakan sertifikat yang menunjukkan bukti atas kepemilikan perusahaan dimana pemegang saham memiliki hak klaim atas penghasilan dan aktiva perusahaan tersebut. Kepemilikan seseorang terhadap suatu perusahaan tergantung dari seberapa besar modal yang ditanamkan di perusahaan tersebut.

Saham merupakan salah satu instrumen pasar keuangan yang paling popular. Menerbitkan saham merupakan salah satu pilihan perusahaan ketika memutuskan untuk menghimpun dana bagi perusahaan. Pada sisi yang lain, saham merupakan salah satu bentuk instrumen investasi yang paling banyak dipilih para investor. Dalam transaksi jual beli di bursa efek, saham atau shares merupakan instrumen yang paling dominan diperdagangkan karena saham mampu memberikan tingkat keuntungan yang menarik.

Saham juga dapat didefinisikan sebagai tanda penyertaan modal seseorang atau badan dalam suatu perusahaan atau perseroan terbatas. Dengan menyertakan modal tersebut, maka pihak tersebut berhak menikmati keuntungan dari perusahaan dan berhak ikut serta dalam Rapat Umum Pemegang Saham (RUPS). Keuntungan yang dinikmati para pemegang saham berasal dari deviden yang diterima dan kenaikan harga saham.

Dalam transaksi jual beli di bursa efek, saham atau sharesmerupakan instrumen yang paling dominan diperdagangkan. Saham tersebut dapat diterbitkan atas nama atau atas tunjuk. Untuk menarik minat para investor yang potensial atau perusahaan selain mengeluarkan saham biasa juga mengeluarkan saham preferen yang dimana investor mempunyai hak-hak prioritas lebih dari saham biasa.

\section{Metode Penelitian}

Lokasi penelitian merupakan tempat dimana peneliti melakukan penelitian untuk memperoleh data - data yang diperlukan berupa laporan keuangan dan sejarah sigkat perusahaan. Penelitian ini dilaksanakan di Bursa Efek Indonesia melalui kantor perwakilan di Makassar yaitu pada Pusat Informasi Pasar Modal (PIPM) yang bertempat di Jln. A. P. Pettarani No. 18 A4 Makassar.

Populasi dalam penelitian ini adalah kelompok perusahaan perbankan yang terdaftar di Bursa Efek Indonesia di tahun 2018. Jumlah perusahaan perbankan yang 
go public di BEI ada 40. Sampel adalah sub kelompok atau sebagian dari populasi (Sekaran, 2006 : 123). Teknik pengambilan yang digunakan yaitu metode Pusposive Sampling. Metode Purposive Sampling yatitu teknik pengambilan sampel sumber data yang didasarkan dengan pertimbangan tertentu. Sampel dalam penelitian ini berjumlah 40 perusahaan perbankan. Pengambilan sampel yang akan diteliti didasarkan pada semua perusahaan perbankan di Bursa Efek Indonesia yang memenuhi kriteria sebagai Perusahaan dengan kapitalisasi pasar terbesar dalam 1 tahun yaitu tahun 2018, perusahaan yang tidak didelisting dalam 1 tahun yaitu tahun 2018 dan perusahaan menerbitkan laporan keuangan lengkap pada 31 Desember tahun 2018.

Dalam penelitian ini penulis membatasi hanya menggunakan beberapa rasio kerangka konseptual yang mencerminkan hubungan antara variable Return on Assets (ROA) (X1), Return on Equity (ROE) (X2), Price Earnings Ratio (PER) (X3), dan Harga Saham (Y).

Metode analisis yang akan digunakan dalam rangka membuktikan hipotesis adalah analisis regresi linier berganda yang dibantu dengan perangkat komputer program "SPSS For Window Versi 20". Uji asumsi klasik sebagai uji persyaratan suatu analisis regresi linier berganda. Dalam pengujian ini uji asumsi klasik terdiri dari uji multikolonieritas, uji normalitas, uji multikolonieritas, uji heteroskedastisitas dan uji autokorelasi. Asumsi klasik penting dilakukan karena merupakan syarat yang harus dipenuhi dalam model regresi agar model tersebut menjadi valid sebagai alat penduga.

Nilai koefisien determinasi adalah antara nol dan satu. Nilai $\mathrm{R}^{2}$ yang kecil berarti kemampuan variabel-variabel independent dalam menjelaskan variasi variabel dependen amat terbatas. Nilai yang mendekati satu berarti variabelvariabel independent memberikan hampir semua informasi yang dibutuhkan untuk memprediksi variasi variabel dependen. Setiap tambahan satu variabel independent, maka $\mathrm{R}^{2}$ akan meningkat tidak peduli apakah variabel tersebut berpengaruh signifikan terhadap variabel dependen.

\section{Hasil Penelitian Dan Pembahasan}

\section{Gambaran Umum Obyek Penelitian}

Perusahaan perbankan dalam penelitian ini merupakan perusahaan jasa perbankan yang go publik di bursa efek indonesia. Penelitian ini dilakukan dengan melihat laporan keuangan yang lengkap dilaporkan dan memiliki data harga pasar saham, sehingga jumlah sampel sebanyak 40 perusahaan perbankan. Penelitian ini dilakukan dalam jumlah tahun selama 1 tahun yaitu pada tahun 2018 sehingga data yang dikumpulkan peneliti berjumlah 40 data keuangan perusahaan perbankan yang terdiri atas Return On Assets (ROA,) Return On Equity (ROE) dan Price Earning Ratio (PER) serta harga saham perusahaan perbankan dengan data keuangan selengkapnya disajikan dalam lampiran I pada penelitian ini.

Perusahaan perbankan yang dijadikan sampel dalam penelitian ini terlihat pada tabel 1 berikut:

Tabel 1

Daftar Sampel Perusahaan Perbankan Yang Go Public

Tahun 2018

\begin{tabular}{|r|c|l|}
\hline No & Kode Bank & \multicolumn{1}{|c|}{ Nama Bank } \\
\hline 1 & AGRS & Bank Agris Tbk \\
\hline 2 & INPC & Bank Artha Graha Internasional Tbk \\
\hline 3 & ARTO & Bank Artos Indonesia Tbk \\
\hline 4 & BRIS & Bank BRIsyariah Tbk \\
\hline 5 & BTPN & Bank BTPN Tbk \\
\hline 6 & BBKP & Bank Bukopin Tbk \\
\hline 7 & BNBA & Bank Bumi Arta Tbk \\
\hline 8 & BACA & Bank Capital Indonesia Tbk \\
\hline 9 & BBCA & Bank Central Asia Tbk. \\
\hline 10 & MCOR & Bank China Construction Bank Indonesia Tbk \\
\hline 11 & BDMN & Bank Danamon Indonesia Tbk \\
\hline 12 & BGTG & Bank Ganesha Tbk. \\
\hline 13 & BBHI & Bank Harda Internasional Tbk. \\
\hline
\end{tabular}




\begin{tabular}{|c|c|c|}
\hline 14 & BINA & Bank Ina Perdana Tbk. \\
\hline 15 & BMRI & Bank Mandiri (Persero) Tbk \\
\hline 16 & BMAS & Bank Maspion Indonesia Tbk. \\
\hline 17 & MAYA & Bank Mayapada Internasional Tbk \\
\hline 18 & BNII & Bank Maybank Indonesia Tbk \\
\hline 19 & MEGA & Bank Mega Tbk \\
\hline 20 & BBMD & Bank Mestika Dharma Tbk. \\
\hline 21 & NAGA & Bank Mitraniaga Tbk. \\
\hline 22 & $\mathrm{BABP}$ & Bank MNC Internasional Tbk. \\
\hline 23 & NOBU & Bank National nobu Tbk. \\
\hline 24 & BBNI & Bank Negara Indonesia (Persero) Tbk \\
\hline 25 & NISP & Bank OCBC NISP Tbk \\
\hline 26 & BSWD & Bank of India Indonesia Tbk \\
\hline 27 & PNBN & Bank Pan Indonesia Tbk \\
\hline 28 & PNBS & Bank Panin Dubai Syariah Tbk. \\
\hline 29 & BEKS & Bank Pembangunan Daerah Banten Tbk. \\
\hline 30 & BJBR & $\begin{array}{l}\text { Bank Pembangunan Daerah Jawa Barat dan } \\
\text { Banten Tbk }\end{array}$ \\
\hline 31 & BJTM & Bank Pembangunan Daerah Jawa Timur Tbk \\
\hline 32 & BNLI & Bank Permata Tbk \\
\hline 33 & BKSW & Bank QNB Indonesia Tbk \\
\hline 34 & BBRI & Bank Rakyat Indonesia (Persero) Tbk \\
\hline 35 & AGRO & Bank Rakyat Indonesia Agroniaga Tbk \\
\hline 36 & BSIM & Bank Sinarmas Tbk \\
\hline 37 & BBTN & Bank Tabungan Negara (Persero) Tbk \\
\hline 38 & BTPS & $\begin{array}{l}\text { Bank Tabungan Pensiunan Nasional Syariah } \\
\text { Tbk. }\end{array}$ \\
\hline 39 & BVIC & Bank Victoria International Tbk \\
\hline 40 & BBYB & Bank Yudha Bhakti Tbk. \\
\hline
\end{tabular}

Sumber : Data diolah oleh peneliti (2019)

\section{Analisis Hasil Penelitian}

\subsection{Pengujian Asumsi Klasik}

\subsubsection{Pengujian Normalitas Data}

Normalitas data merupakan asumsi yang sangat mendasar dalam analisis multivariasi. Pengujian normalitas bertujuan untuk menguji data dalam model regresi, yaitu variabel pengganggu atau residual telah terdistribusi normal atau tidak mengacu pada sarwono \& suhayati (2010). Model regresi yang baik adalah data yang berdistribusi normal atau mendekati normal. Salah satu cara dalam menguji normalitas adalah menggunakan analisis grafik yang dideskripsikan dengan normal probably plot. Normal probably plot membandingkan distribusi kumulatif dari data sesungguhnya dengan distribusi kumulatif dari

distribusi normal. Distribusi normal akan membentuk satu garis lurus diagonal dan ploting data dibandingkan dengan garis diagonal. Jika distribusi data adalah normal, maka garis yang menggambarkan data sesungguhnya akan mengikuti garis diagonalnya.

Adapun dasar dari pengambilan keputusan pada grafik Normal P-P Plot, yaitu:

- Jika pola data menyebar di sekitar garis diagonal serta mengikuti arah garis diagonal maka model regresi memenuhi asumsi normalitas.

- Jika pola data menyebar jauh di sekitar garis diagonal serta tidak mengikuti arah garis diagonal maka model regresi tidak memenuhi asumsi normalitas.

- Tes normalitas bisa juga dilihat dari tes normalitas menggunakan Kolmogrov-Smirnov. 


\section{Tabel 2}

\begin{tabular}{|c|c|c|}
\hline \multicolumn{3}{|c|}{$\begin{array}{c}\text { One-Sample Kolmogorov-Smirnov } \\
\text { Test }\end{array}$} \\
\hline & & $\begin{array}{l}\text { Unstandardized } \\
\text { Residual }\end{array}$ \\
\hline \multicolumn{2}{|l|}{$\mathrm{N}$} & 35 \\
\hline \multirow{2}{*}{$\begin{array}{l}\text { Normal } \\
\text { Parameters }{ }^{\mathrm{a}, \mathrm{b}}\end{array}$} & Mean &, 0000000 \\
\hline & $\begin{array}{l}\text { Std. } \\
\text { Deviation }\end{array}$ & 1,66239888 \\
\hline \multirow{3}{*}{$\begin{array}{l}\text { Most } \\
\text { Extreme } \\
\text { Differences }\end{array}$} & Absolute & , 108 \\
\hline & Positive & , 108 \\
\hline & Negative &,- 088 \\
\hline \multicolumn{2}{|l|}{ Test Statistic } & , 108 \\
\hline \multicolumn{2}{|c|}{ Asymp. Sig. (2-tailed) } & $200^{\mathrm{c}, \mathrm{d}}$ \\
\hline
\end{tabular}

a. Test distribution is Normal.

b. Calculated from data.

c. Lilliefors Significance Correction.

$\mathrm{d}$. This is a lower bound of the true significance.

Sumber: Data diolah (2019)

- Normalitas data dapat dilihat dengan menggunakan KolmogrovSmirnov. Jika nilai KolmogrovSmirnov lebih besar dari $\alpha=0,05$, maka data normal (Ghizali, 2006 :152). Uji Kolmogrov-Smirnov dilakukan dengan membuat hipotesis:

- Ha : Data residual terdistribusi normal, apabila sig.2-tailed $>\alpha=$ 0,05

- Ho : Data residual tidak terdistribusi normal, apabila sig.2tailed $<\alpha=0,05$

- Dari hasil tes normalitas dengan menggunakan Kolmogrov-Smirnov dapat kita lihat kalau nilai Kolmogrov-Smirnov adalah sebesar 0,2 lebih besar dari $\alpha=$ 0,05, maka data normal dan terdistribusi normal.

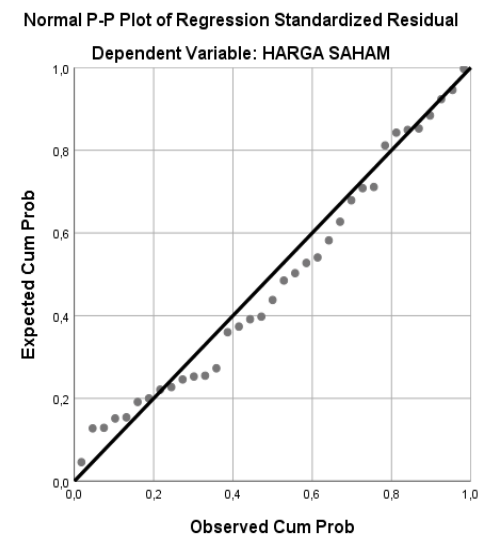

\section{Gambar 1 Grafik Uji Normalitas Residual P.Plot}

Selain itu, normal atau tidaknya suatu bias dilihat dari kurva distribusi yang dapat dilihat dari plot grafik histogram. Data yang berdistribusi normal adalah data yang berpola terpusat tidak condong ke kiri atau ke kanan.

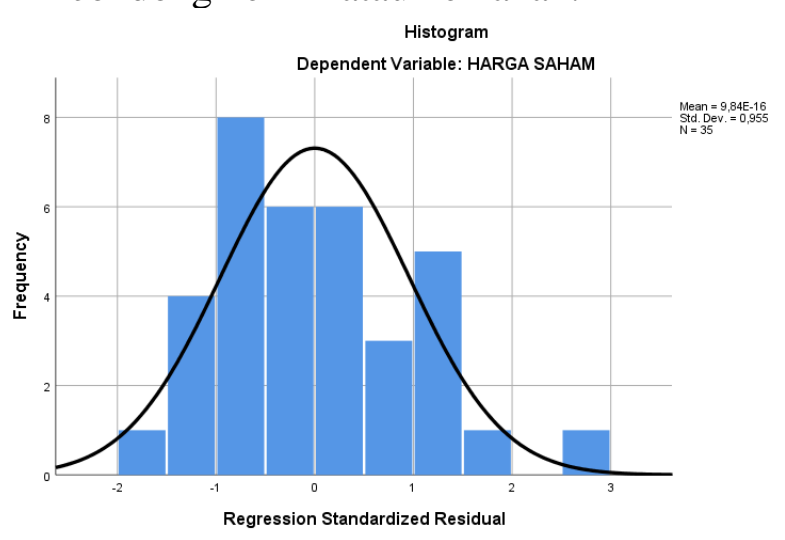

\section{Gambar 2 Grafik Uji Normalitas Residual Histogram}

Pada grafik histogram memberikan pola distribusi yang terpusat tidak condong ke kiri atau ke kanan yang artinya adalah data berdistribusi normal Grafik P-Plot terlihat bahwa pola titik-titik berupa data menyebar di sekitar garis diagonal dan tidak terpencar jauh serta mengikuti arah garis diagonal. Sehingga dapat disimpulkan bahwa model regresi layak digunakan karena memenuhi asumsi normalitas.

\subsubsection{Pengujian Multikolinearitas}

Uji Multikolinearitas bertujuan untuk menguji apakah variabel independen saling berhubungan (korelasi) atau tidak berhubungan dalam model regresi pada 
model regresi yang baik seharusnya tidak terjadi korelasi antar variabel independen. Indikator untuk mengetahui ada atau tidaknya multikolinearitas dapat dideteksi dengan melihat Variance Inflation Factor (VIF). Dasar pengambilan keputusan adalah sebagai berikut:

a. Jika Variance Inflation Factor (VIF) lebih dari 10 dan Tolerance kurang dari 0,1 maka artinya terjadi multikolinearitas di antara variabel bebas.

b. Jika Variance Inflation Factor (VIF) kurang dari 10 dan Tolerance lebih dari 0,1 maka artinya tidak terjadi multikolinearitas di antara variabel bebas.

Pengujian multikolinearitas pada penelitian ini dilakukan dengan melihat nilai colinearity statistics dan nilai koefisien korelasi di antara variabel bebas. Hasil pengujian terlihat pada tabel 3 sebagai berikut:

\section{Tabel 3}

\section{Coefficients $^{\text {a }}$}

\begin{tabular}{|c|c|c|c|}
\hline \multirow{2}{*}{\multicolumn{2}{|c|}{ Model }} & \multicolumn{2}{|c|}{$\begin{array}{c}\text { Collinearity } \\
\text { Statistics }\end{array}$} \\
\hline & & Tolerance & VIF \\
\hline \multirow[t]{3}{*}{1} & ROA &, 158 & 6,338 \\
\hline & ROE &, 120 & 8,332 \\
\hline & PER & ,439 & 2,277 \\
\hline
\end{tabular}

a. Dependent Variable: HARGA SAHAM

Sumber: Data diolah (2019)

Berdasarkan output di atas maka dapat kita lihat bahwa nilai Tolerance semua variabel bebas lebih dari 0,1000 dan memiliki nilai VIF kurang dari 10. Hal ini berarti bahwa tidak terjadi multikolinearitas antara variabel bebas Return On Assets, Return On Equity dan Price Earning Ratio.

Nilai yang umum dipakai adalah nilai tolerance sebesar 0,1 atau sama dengan nilai VIF sebesar 10 (Ghozali, 2006 : 96). Jika VIF > 10 atau jika tolerance $<0,1$ maka ada multikolinearitas dalam model regresi.

\subsubsection{Uji autokorelasi}

Autokorelasi merupakan korelasi antara anggota observasi yang disusun menurut waktu atau tempat. Model regresi yang baik seharusnya tidak terjadi autokorelasi. Uji autokorelasi bertujuan untuk menguji apakah dalam suatu model regresi linear ada korelasi antara kesalahan pengganggu pada periode $\mathrm{t}$ dengan kesalahan periode t-1 (sebelumnya). Jika terjadi korelasi maka dinamakan ada masalah autokorelasi. Gejala autokorelasi dapat dideteksi dengan menggunakan uji Durbin-Watson (DW) pada tabel model summary. Metode pengujian menggunakan uji Durbin Watson (DW West). Pengambilan keputusan pada uji Durbin Watson adalah sebagai berikut.

a. Apabila $\mathrm{dU}<\mathrm{DW}<4-\mathrm{dU}$ maka hipotesis nol (Ho) diterima, jadi tidak terjadi autokorelasi.

b. Apabila dU<DW $<4-d L$ maka hipotesis nol (Ho) ditolak, artinya terjadi autokorelasi.

c. Apabila dU $<$ DW $<$ dU atau 4 $\mathrm{dU}<\mathrm{DW}<4$-dL artinya tidak ada kepastian atau kesimpulan yang pasti.Nilai DL dan DU dapat diperoleh dari tabel statistic Durbin Watson dengan $\mathrm{n}=40$ dan $\mathrm{k}=$ 3 (k adalah jumlah variabel independen) Didapat $\mathrm{DL}=$ 1,3384 dan DU= 1,6589.

Hasil Uji autokorelasi dapat dilihat pada output hasil regresi dan ditampilkan dalam tabel sebagai berikut:

\section{Tabel 4}

\begin{tabular}{|c|c|c|c|c|c|}
\hline \multicolumn{6}{|c|}{ Model Summary } \\
\hline Model & $\mathrm{R}$ & $\begin{array}{c}\mathrm{R} \\
\text { Square }\end{array}$ & $\begin{array}{c}\text { Adjusted } \\
\text { R } \\
\text { Square }\end{array}$ & $\begin{array}{c}\text { Std. } \\
\text { Error of } \\
\text { the } \\
\text { Estimate }\end{array}$ & $\begin{array}{l}\text { Durbin- } \\
\text { Watson }\end{array}$ \\
\hline 1 & $694^{\mathrm{a}}$ & 482 & .432 & 25,06765 & 2,308 \\
\hline
\end{tabular}

a. Predictors: (Constant), PER, ROA, ROE

b. Dependent Variable: HARGA SAHAM

Sumber: Data diolah (2019)

Dari output di atas dapat diketahui nilai Durbin Watson sebesar 2,308. $\mathrm{N}=40, \mathrm{dl}=1,3384$, 
$\mathrm{du}=1,6589,4-\mathrm{dl}=2,6616,4-\mathrm{du}$ $=$ 2,3411. Karena nilai DW terletak antara DU $<$ D W $<4$ DU $(1,6589<2,308<2,3411)$ maka Ho diterima, artinya tidak terjadi autokorelasi.

\subsubsection{Uji heteroskesdastisitas}

Uji heteroskedastisitas menguji terjadinya perbedaan variance residual suatu periode pengamatan ke periode pengamatan yang lain atau gambaran hubungan antara nilai yang diprediksi dengan Studentized Delete Residual nilai tersebut. Model regresi yang baik adalah model regresi yang memiliki persamaan variance residual suatu periode pengamatan yang lain, atau adanya hubungan antara nilai yang diprediksi dengan Studentized Delete Residual nilai tersebut sehingga dapat dikatakan model tersebut homokesdastisitas.

Cara memprediksi ada tidaknya heteokesdastisitas pada suatu model dapat dilihat dari pola gambar Scatterplot model tersebut. Analisis pada gambar Scatterplot yang menyatakan model regresi linier berganda tidak terdapat heterokesdastisitas jika:

1. Titik - titik tidak menyebar di atas dan di bawah atau disekitar angka 0.

2. Titik - titik data tidak mengumpul hanya di atas atau di bawah saja.

3. Penyebaran titik - titik data tidak boleh membentuk pola bergelombang melebar kemudian menyempit atau melebar kembali.

4. Penyebaran titik - titik data sebaiknya tidak berpola.

Maka dapat disimpulkan bahwa model regresi linier berganda terbebas dari asumsi klasik heterokesdastisitas dan layak digunakan dalam penelitian (Nugroho, 2005 : 62).

Jika tidak ada pola yang jelas, seperti titik-titik menyebar di atas dan di bawah angka 0 pada sumbu $\mathrm{Y}$, maka tidak terjadi heteroskedastisitas. Hasil uji Heteroskedastisitas dapat dilihat pada output hasil regresi, dan ditampilkan dalam gambar berikut ini:

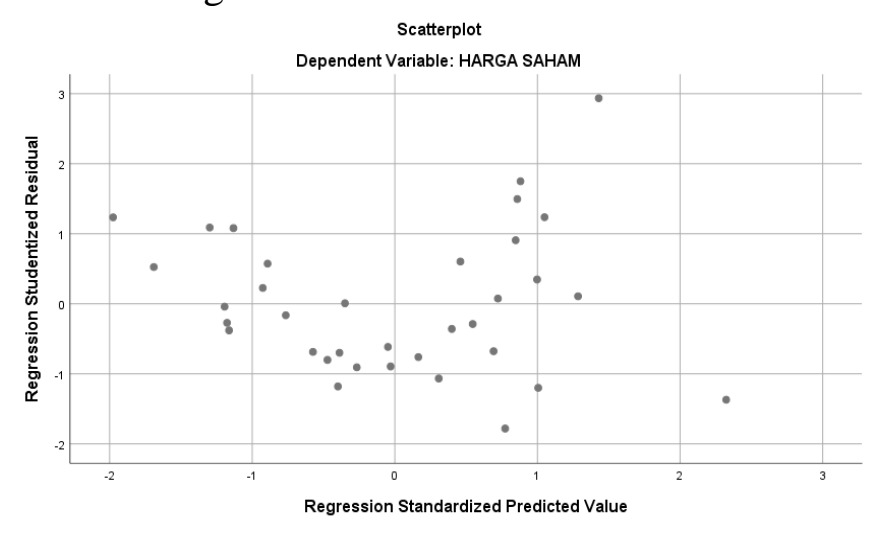

Grafik 3 Grafik

Scatterplot Hasil Uji Heteroskedastisitas

Dari output dapat filihat bahwa titiktitik tidak membentuk pola yang jelas, dan titik-titik menyebar di atas dan di bawah 0 pada sumbu Y. Jadi dapat disimpulkan bahwa tidak terjadi heteroskedastisitas dalam model regresi.

\subsection{Uji Regresi Linear Berganda}

Regresi bertujuan untuk menguji hubungan pengaruh antara satu vaiabel terhadap variabel lain. Regresi yang memiliki satu variabel dependen dan lebih dari satu variabel independen disebut regresi berganda (Nugroho, 2005 : 43). Model persamaannya dapat digambarkan sebagai berikut: $\mathrm{Y}=\alpha+\beta 1 \mathrm{X} 1+\beta 2 \mathrm{X} 2+\beta 3 \mathrm{X} 3+$ $\varepsilon$

Keterangan: perbankan

$\mathrm{Y}=$ Harga saham

$\alpha=$ Konstanta

$\mathrm{X} 1=\mathrm{ROA}$

$\mathrm{X} 2=\mathrm{ROE}$

$\mathrm{X} 3=\mathrm{PER}$

$\beta 1, \quad \beta 2, \quad \beta 3=$ Koefisien regresi parsial untuk $\mathrm{X} 1, \mathrm{X} 2, \mathrm{X} 3$ 
Tabel 5

Hasil Uji T

\begin{tabular}{|c|c|c|c|c|c|}
\hline \multicolumn{6}{|c|}{ Coefficients $^{\mathbf{a}}$} \\
\hline & $\begin{array}{l}\text { Unstan } \\
\text { Coeff }\end{array}$ & $\begin{array}{l}\text { ardized } \\
\text { cients }\end{array}$ & $\begin{array}{l}\text { Standardized } \\
\text { Coefficients }\end{array}$ & & \\
\hline Model & B & $\begin{array}{l}\text { Std. } \\
\text { Error }\end{array}$ & Beta & $\mathrm{t}$ & Sig. \\
\hline (Constant) & $\begin{array}{r}- \\
26,252\end{array}$ & 19,928 & & $\begin{array}{r}- \\
4,317\end{array}$ &, 000 \\
\hline ROA & 7,437 & 20,420 & ,119 & 2,364 & ,018 \\
\hline ROE & 19,737 & 10,873 & 677 & 3,815 & ,019 \\
\hline PER & 1,216 & 1,758 & , 135 & 2,692 &, 004 \\
\hline
\end{tabular}

a. Dependent Variable: HARGA SAHAM

Dari tabel 5 di atas formula persamaan regresi diperoleh sebagai berikut:

$$
\begin{array}{r}
\text { Harga Saham }=(-26,252)+ \\
7,437 \mathbf{X} \mathbf{1}+19,737 \mathbf{X} \mathbf{2}+1,216 \mathbf{X 3}
\end{array}
$$

Dari persamaan tersebut di atas bahwa koefisien regresi linier dari variabel bebas ROA, ROE, dan PER bertanda positif, yang berarti variabel bebasnya mempunyai pengaruh searah dengan variabel tidak bebas. Jadi jika ROA, ROE, dan PER meningkat akan berpengaruh terhadap peningkatan harga saham. Sebaliknya jika ROA, ROE, dan PER menurun akan berpengaruh terhadap penurunan harga saham.

\section{Koefisien Regresi ROA}

Koefisien regresi ROA bertanda positif secara matematis, hal ini berarti bahwa harga saham perusahaan perbankan yang go public di bursa efek indonesia akan naik sebesar 7,437 kali apabila terjadi kenaikan $1 \%$ pada ROA jika variabel independen yang lainnya tetap. Kenyataan ini sesuai dengan teori yang ada, yang mengatakan bahwa pada dasarnya semakin tinggi ROA maka semakin baik produktivitas assets dalam memperoleh keuntungan bersih. Hal ini selanjutnya akan meningkatkan daya tarik perusahaan kepada investor. Peningkatan daya tarik perusahaan tersebut makin diminati investor karena tingkat pengembalian akan semakin besar. Hal ini juga akan berdampak pada harga saham dari perusahaan.

\section{Koefisien Regresi ROE}

Koefisien regresi ROE bertanda positif secara matematis, hal ini berarti bahwa harga saham perusahaan perbankan yang go public di bursa efek indonesia akan naik sebesar 19,737 kali apabila terjadi kenaikan $1 \%$ pada ROE jika variabel independen yang lainnya tetap. Hasil penelitian ini sesuai dengan teori yang ada, yang menyebutkan bahwa semakin tinggi return atau penghasilan yang diperoleh semakin baik kedudukan pemilik perusahaan dan tentu saja konsekuensi logisnya adalah semakin menigkatkan pula kesejahteraan para pemegang saham perusahaan yang bersangkutan sehingga harga saham akan ikut meningkat.

\section{Koefisien Regresi PER}

Koefisien regresi PER bertanda positif secara matematis, hal ini berarti bahwa harga saham perusahaan perbankan yang go public di bursa efek indonesia akan naik sebesar 1,216 kali apabila terjadi kenaikan 1 rupiah pada PER jika variabel independen yang lainnya tetap. Adanya pengaruh signifikan PER terhadap harga saham mengindikasikan bahwa investor menilai prospek pertumbuhan laba suatu perusahaan. Artinya, pertumbuhan laba suatu perusahaan dinilai tinggi jika PER perusahaan tersebut lebih tinggi apabila dibandikan dengan PER perusahaan lain dalam industri sejenis. Semakin tinggi PER, maka penghargaan pasar akan saham perusahaan tersebut akan semakin tinggi sehingga harga saham cenderung akan naik.

\section{Pembahasan}

Berdasarkan hasil analisis di atas dalam rangka mencari pemecahan masalah pada penelitian ini, dapat tergambar dengan jelas bahwa tujuan penelitian dapat tercapai.

\section{Return On Assets (ROA)}

Dari hasil uji t pada Tabel 5, secara parsial faktor fundamental 
ROA memiliki pengaruh yang signifikan terhadap harga saham dan koefisien yang dihasilkan menunjukkan nilai positif. Hal ini sesuai dengan teori yang mengatakan bahwa ROA berpengaruh terhadap harga saham, semakin tinggi ROA suatu perusahaan akan meningkatkan daya tarik investor terhadap perusahaan tersebut dan menjadikan perusahaan tersebut menjadi perusahaan yang diminati oleh banyak investor karena tingkat pengembalian akan semakin besar. Minat yang besar dari investor berdampak terhadap kenaikan harga saham.

Berpengaruhnya ROA terhadap harga saham mengindikasikan bahwa sebagian besar investor tertarik untuk mendapatkan laba jangka panjang berupa dividend sehingga dalam mempertimbangkan pembelian saham mempertimbangkan ROA perusahaan.

\section{Return On Equity (ROE)}

Dari hasil uji t pada tabel 5 secara parsial faktor fundamental return on equity (ROE) memiliki pengaruh yang signifikan terhadap harga saham dan koefisien yang dihasilkan menunjukkan nilai positif. Adanya pengaruh signifikan ROE terhadap harga saham mengindikasikan bahwa kinerja perusahaan perbankan semakin efisien dalam menggunakan modal sendiri. Untuk menghasilkan laba atau keuntungan bersih sehingga rasio $\mathrm{ROE}$ perusahaan semakin tinggi. Rasio ROE yang tinggi cenderung meningkatkan minat investor terhadap saham karena menganggap perusahaan tersebut mempunyai prospek yang baik dalam meningkatkan laba. Apabila minat investor meningkat terhadap suatu saham, maka harga saham tersebut akan meningkat.
Berdasarkan hasil uji parsial (uji t) tersebut ROE mempunyai pengaruh dominan terhadap harga saham dibandingkan dengan ROA dan PER. Hal ini ditunjukkan dengan angka hasil pengujian ROE lebih besar dibandingkan ROA dan PER. Hasil ini menunjukkan bahwa investor lebih memperhatikan variabel fundamental yaitu Return On Equity ( ROE), karena ROE merupakan informasi yang dapat menunjukkan kemampuan bank dalam menghasilkan laba bersih dikaitkan dengan pembayaran dividen. Semakin besar ROE menunjukkan kenaikan laba bersih dari bank yang bersangkutan.

3. Price Earning Ratio (PER)

Dari hasil uji t pada tabel 5, secara parsial faktor fundamental price earning ratio (PER) memiliki pengaruh yang signifikan terhadap harga saham properti dan koefisen yang dihasilkan menunjukkan nilai positif 1,216. Adanya pengaruh signifikan PER terhadap harga saham mengindikasikan bahwa investor menilai prospek pertumbuhanlaba suatu perusahaan. Artinya, pertumbuhan laba suatu perusahaan dinilai tinggi jika PER perusahaan tersebut lebih tinggi apabila dibandingkan dengan PER perusahaan lain dalam industri sejenis. Semakin tinggi PER, maka penghargaan pasar akan saham perusahaan tersebut akan semakin tinggi sehingga harga saham cenderung akan naik. Akan tetapi bagi investor yang ingin membeli saham suatu perusahaan, semakin kecil PER suatu saham akan semakin baik karena harga saham tersebut murah.

Dari hasil uji simultan (uji F) pada analisis regresi linear berganda, terbukti bahwa ketiga variabel independen yaitu ROA, ROE, dan PER secara simultan/ bersama-sama mempunyai 
pengaruh yang signifikan terhadap variabel dependen dengan harga saham perusahaan perbankan yang go public di bursa efek indonesia.

\section{Kesimpulan}

Berdasarkan hasil analisis dan pembahasan pada $\mathrm{BAB} V$ sebelumnya dapat disimpulkan hal-hal sebagai berikut:

1. Seluruh variabel independen (bebas)

yang terdiri atas Return On Assets (ROA), Return On Equity (ROE), dan Price Earning Ratio (PER) secara simultan berpengaruh signifikan terhadap variabel dependen (tidak bebas) yaitu harga saham perusahaan perbankan yang go public di Bursa Efek Indonesia.

2. Return On Assets (ROA) secara parsial berpengaruh signifikan terhadap harga saham perusahaan perbankan yang go public di bursa efek indonesia. Return On Equity (ROE) dan Price Earning Ratio (PER) secara parsial berpengaruh signifikan terhadap harga saham perusahaan perbankan yang go public di bursa efek indonesia.

Berdasarkan kesimpulan di atas, penulis memberikan saran-saran sebagai berikut:

1. Bagi para investor yang akan menanamkan modalnya khususnya pada perusahaan perbankan yang go public di bursa efek indonesia, agar perlu mempertimbangkan variabelvariabel yang mempengaruhi harga saham perusahaan, terutama variabel Return On Equity (ROE) yang dimiliki perusahaan tersebut. Karena variabel tersebut berpengaruh terhadap harga saham perusahaan.

2. Bagi perusahaan obyek penelitian ini dapat dipertimbangkan dalam melakukan peningkatan usahanya, terutama yang berkaitan dengan Return On Equity (ROE) agar harga saham perusahaan meningkat.

3. Bagi peneliti lain yang akan melakukan penelitian dapat dipakai sebagai bahan acuan dalam penelitiannya. Serta disarankan agar melakukan penelitian lanjutan pada tahun-tahun mendatang pada variabelvariabel yang berbeda atau pada perusahaan-perusahaan yang lain.

\section{Daftar Pustaka}

Fahmi, Irham. 2012. Pengantar Pasar Modal. Bandung: Penerbit Alfabeta.

Ghozali,Imam. 2006. Aplikasi Analisis Multivariate dengan Program SPSS. Semarang: BP Universitas Diponegoro.

Halim, Abdul. 2005. Analisis Investasi Edisi 2. Jakarta: Salemba Empat.

Handoko, Wahyu. 2008. Pengaruh Economic Value Added, ROE, ROA dan EPS Terhadap Perubahan Harga Saham Perusahaan Kategori LQ45 Pada Bursa Efek Jakarta. Universitas Muhammadiyah Surakarta.

Hasanah, Deasy. 2010. Pengaruh ROA, ROE dan EPS Terhadap Harga Pasar Saham Pada Perusahaan Food and Beverages yang Go Publik di Bursa Efek Indonesia (BEI). Undergraduate thesis, UPN "Veteran" Jatim. Jurnal Ekonomi dan Manajemen. UPN Jatim.

Hanafi \& Halim. 2007. Analisis Laporan Keuangan. Yogyakarta: UPP STIM YKPN.

Hermuningsih, Sri. 2012. Pengantar Pasar Modal Indonesia. Yogyakarta: UPP STIM YKPN.

Husnan, Suad. 2013. Dasar-Dasar Teori Portofolio dan Analisis Sekuritas 
Edisi Ketiga. Yogyakarta: AMP YKPN.

Musthafa, 2013. Manajemen Keuangan. Surabaya. Badan Penerbit STIE Mahardhika.

Nugroho, Bhouno Agung. 2005. Strategi Jitu Memilih Metode Statistik Penelitian dengan SPSS. Yogyakarta: Penerbit Andi.

Nurhasanah, Rahmaliah. 2014. Pengaruh Return on Assets (ROA), Return on Equity (ROE) dan Earning Per Share (EPS) terhadap Harga Saham. Jurnal Akuntansi. Universitas Widyatama Bandung.

Nurmalasari, Indah. 2008. Analisis Pengaruh Rasio Profitabilitas Terhadap Harga Saham Emiten LQ45 Yang Terdaftar Di Bursa Efek Indonesia Tahun 2005-2008. Jurnal Ekonomi dan Manajemen. Universitas Gunadarma.

Pakarti \& Anoraga. 2008. Pengantar Pasar Modal. Jakarta: Rineka Cipta.

Ramli, Anwar. 2010. Pengantar Statistik untuk Ekonomi dan Manajemen. Jakarta: Orbit.

Rinati, Ina. 2008. Pengaruh Net Profit Margin (NPM), Return On Assets (ROA) dan Return On Equity (ROE) terhadap Harga Saham pada Perusahaan yang Tercantum Indeks LQ45. Jurnal Ekonomi dan Manajemen. Universitas Gunadarma.

Safitri, Abied Luthfi. 2013. Pengaruh Earning Per Share, Price Earning Ratio, Return On Asset, Debt to Equity Ratio dan Market Value Added terhadap Harga Saham dalam Kelompok Jakarta Islamic Index. Jurnal Manajemen. Universitas Diponegoro.
Samsul, Mohamad. 2006. Pasar Modal dan Manajemen Portofolio. Jakarta: Penerbit Erlangga.

Spartha \& Februwaty. 2005. "Pengaruh ROE, EPS dan OCF Terhadap Harga Saham Industri Manufacturing Di Bursa Efek Jakarta”. Jurnal Akuntansi. Jakarta: FE Universitas Tarumanegara.

Sugiyono. 2014. Metode Penelitian Kuantitatif, Kualtatif dan Kombinasi (Mixed Methods). Bandung: Alfabeta.

Sugiyono. 2013. Metode Penelitian Bisnis. Bandung: Alfabeta.

Susilawati, Crhistine Dwi Karya. 2005. Pengaruh Rasio Keuangan terhadap Harga Saham Perusahaan Perbankan pada Tahun 2008 - 2011. Semarang: Universitas Dian Nuswantoro.

Syamsuddin, Lukman. 2007. Manajemen Keuangan Perusahaan: Konsep Aplikasi dalam Perencanaan, Pengawasan dan Pengambilan Keputusan (Edisi Baru). Jakarta: PT. Raja Persada.

Tandelilin, Eduardus. 2010. Portofolio dan Investasi Teori dan Aplikasi. Yogyakarta: Kanisius.

Weston \& Copeland. 2010. Manajemen Keuangan. Tangerang: Binarupa Aksara.

Wild, Subramanyam \& Halsey. 2005. Analisis Laporan Keuangan. Jakarta: Salemba Empat. 